\title{
The Role of the Imam in Leading American Mosques
}

\author{
Imam John Ederer*
}

\begin{abstract}
Across the country, American mosques are struggling with dwindling attendance and/or stagnancy. The causes generally come back to four interconnected points: a lack of governing principles, the politics of control by personalities, little focus on social integration, and a scarcity of properly trained and empowered imams. The imam, the community's leading inspirational motivating force, is governed by scripture and both supported as well as held accountable by a community rooted in scriptural values. These values are a broad realm of massive differences subject to an array of cultures that can be a cause for division.

Given this reality, Muslims must establish a mission, vision, and core value system for a clear cohesive divinely guided community. This system must prioritize the community's relevant needs with a strong focus on the big picture of Islam as it relates to the broader society. The administrative management of mosques should support their imam to lead them accordingly.
\end{abstract}

Keywords: Imam, mosque, culture, custom, citizenship

\section{Introduction}

The historic concept of the mosque's role in society has strayed from its prophetic roots throughout the Muslim world, where they generally exist as no more than a place to pray șalät al-jum 'a (the congregational Friday prayer) for most men and maybe some women. The five daily prayers are attended by a much smaller group of men and almost no women or youth. In some mosques, there are some small reflections or lessons given after prayer.

While in some aspects our modern reality requires a different approach, we have still strayed from the spirit of the sacred model that the Prophet established in Madina. An imam must lead the way in developing faith as an active component of the congregation. The idea of a mosque being a multifaceted home away

\footnotetext{
* Imam John Ederer, currently serving at the Muslim Community Center of Charlotte, North Carolina, studied formally at the Islamic American University (Michigan) and the Diwan Center (Egypt). He also spent five years studying classical texts with prominent scholars in Egypt and Kuwait. https://charlottemcc.org/imam-john-ederer.
} 
from home rooted in its leadership's developing and mobilizing the believers is now practically extinct.

In this paper we analyze the unique opportunity in America to revive the Prophet's example of leading a community of believers and seek to understand this role as it relates to the American context. Carefully assessing and learning how to overcome the struggles of establishing this model is crucial for this endeavor's success. We discuss two sociological surveys that utilize data acquired by researching and surveying the landscape of mosque culture and argue that leadership is key to formulating a priority-based system.

The basis for a healthy model is rooted in a well-crafted mission, vision, and core value system that can hold both the imam and the congregation accountable. Muslims can learn from the successful models of other faith communities in this country. In short, the American Muslim community can flourish only if its members realize, promote, and prioritize the mosque's role.

\section{Diagnosing the Problem}

While traveling across this country for the last ten years, I have seen a growing decline in mosque attendance, especially among women and younger people born and raised here. This phenomenon gave birth to the "unmosqued" movement. Some of its members made a documentary featuring disenfranchised Muslims and prominent imams who share their concerns about this growing phenomenon. This term refers to the nationwide problem of mosques declining in stable attendance and vitality. As a result, third spaces, defined as a social theory according to which a group feels that they must create a new space as a result of unequal and uneven forces of cultural representation (Bhabah 2004), have been popping up nationwide. This growing crisis can be solved by mosque boards and imams assessing their communities' culture, goals, and priorities.

The Hartford Institute for Religion and Research from laid out this phenomenon in a large-scale mosque studies report conducted in 2011. This report found various factors that are hindering the success of most American mosques, among them the following:

- Massive understaffing. Only $44 \%$ of imams have full-time paid salaries. More than half of all mosques have no full-time paid staff, $19 \%$ have no imam at all, and only 5\% have at least two full-time paid staff. Many churches point to a ratio of 1:100 for full-time paid staff to weekly attendees (Schaller, 1980).

- A lack of relevance. It noted that $85 \%$ of full-time paid imams are immigrants with relatively no experience in the US and that $30 \%$ of imams deliver the Friday sermon in languages other than English. Imams almost exclusively study Islamic studies and jurisprudence, and thus $96 \%$ of their degrees were obtained overseas. 
- A lack of representative diversity. Only $18 \%$ of the attendees of the Friday sermon are women, only $59 \%$ of mosques have women serving on the board, and 63\% of them score between "poor" and "fair" as womenfriendly spaces. Outside of the significant W.D. Muhammad African American community, almost all mosques have a separate room or partition for women. Mosques with gender-segregated space have lower numbers of outreach activities, community service projects, and sociopolitical activism. Two-thirds of mosques do not consider youth groups and programs as being among their top priorities. Unfortunately, only $6 \%$ of Friday sermons are attended by school children.

These concerns led to a thorough scientific analysis and conclusion from the Institute for Social Policy and Understanding (ISPU; www.ispu.org). Joining forces with the unmosqued team and Hartford Institute researches, they combined data and published "Reimagining Muslim Spaces," a multi-layered report available on their website. Its main findings led to the following suggestions, which mirror the concerns addressed in the previously cited data from the Hartford report. These suggestions are supported by a diverse body of American imams, scholars of Islam and Muslim social scientists.

- The key element of a healthy thriving mosque model is to be welcoming and inclusive. Some people fear that such a statement promotes liberal mosques. And yet there is no indication that they are suggesting normalizing or accommodating people who promote non-confirmative beliefs and practices. Rather, the report is calling upon the mosque to be a place in which each person, whether Muslim or non-Muslim, is appreciated and may grow in his or her knowledge and practice of Islam.

This replaces a culture of judgment based on immediate expectations of a certain level of knowledge and practice of Islam. Such a new culture requires a mature understanding of the Prophet's biography as it relates to the Quran's messaging from Makka to Madina. Such communal maturity leads to a proper understanding and application of Islamic priorities.

- Next, a mosque can excel in governance only when it has adequate staffing with competitive means. This governing body must be transparent and inclusive.

- Lastly, the mosque should be a hub for hope, a place where Muslims can look forward to their own growth as believers. This spiritual community naturally serves the broader society.

The report also crunches the data as it relates to the sociology of the American Muslim community. I highly encourage everyone to read the entire report, which touches upon a few issues that are of considerable significance. I will expound upon these below. 
My experience is that two underlying factors account for this mosque stagnancy and decline in our community. First, the current judgmental or nitpicking attitude basically amounts to a lack of wisdom in understanding Islam's priorities or respect for Muslims' differences of opinion. Some examples of this are enforcing dress codes, gender mixing, and food issues. This will be addressed in the core values at the end of this paper.

Second, recreating and standardizing immigrant cultures and languages as defining features of the mosque experience. These nationwide phenomena across many mosques are major forces behind the appearance of third spaces and the lack of interest from women and the generation raised here.

\section{The Qualified Imam}

Prophet Muhammad was the greatest leader in world history. As a non-Muslim historian put it, he was the most influential man in history (Hart 1992). Adding revelation to the Prophet's impeccable character gave him the knowledge base needed to effectively convey divine guidance to his people and beyond.

In my first role as an imam in 2009 , I vividly remember sitting with a group of community members during a family night intended to welcome the new imam. A board member leaned toward me just as we started to eat and asked, "If the Prophet were here with us now, would he sit at a table and eat with a spoon?" I replied "Yes, of course," and explained that he sat on the floor and ate with his hand simply because that was his society's norm and was not a specific revelation. Many Muslims focus heavily on the outward or cultural aspect of the Prophet's reality, which can lead to a superficial symbolic affiliation rather than the spiritual attention we all need so much.

I explained to him that the Prophet is the best example to be followed (33:21). Some scholars believe the verse refers to everything about him, whereas others, given the verse's context, contend that is focusing on the spiritual side that comes from the heart and is empowered through revelation. The verse's end proclaims that he is an example "for whoever hopes to have God's contentment in the afterlife." We appreciate the fact that the Prophet was an Arab, but as believers we are to take him as our spiritual example in how to embody Islam. In fact, the Quran emphasizes this point by instructing the Prophet to "tell them I am only a man like you all, except I have received revelation..." (18:110).

Let's first highlight the key character traits of the man God chose for the ultimate role of leadership, for prioritizing them will enable us to carry this message and communicate it to the world successfully. When the Quraysh were rebuilding the Ka'bah almost fifteen years before the revelation began, they quarreled over who should reinsert the Black Stone in its place. They finally decided that whoever would enter next would be tasked with the decision. Muhammad entered, and they sighed, stating, "This is the most trustworthy [man] among us, 
and we are pleased with his judgment" (Ṭabarānī, Mu 'jam al-Awsaț, volume 3, hadith no. 50).

After receiving his first revelation in the Hira cave, the Prophet was deeply confused and thought that something had afflicted him. His wife Khadija consoled him, saying, "God would never allow anything to afflict you. You keep good ties of kinship, you are an honest man, you care for the weak, you go out of your way for those in need, you are most hospitable to your guests, and you support truth and justice" (Sahịh Muslim, hadith no. 231). When he announced his prophethood to his extended family - members of the Hashim clan of the Quraysh tribe - asking if they would believe what he would tell them, they replied, "We have never known you to tell a lie!" (Șậ̄h al-Bukhārī, hadith no. 4770).

Honesty, trust, and integrity are the three distinct traits of successful leadership (Bennet 1993). A quick googling of it reveals countless modern self-help gurus who swear by them. After the Prophet assumed the young community's leadership, he used these essential traits to maintain the ideal dynamic between a leader and his followers. God summed up the secret of his success as, "It was by God's mercy that you are gentle with them. Had you been rigid or harsh hearted they would have surely abandoned you. So pardon them, seek forgiveness for them and consult with them in decision making. Once you make a decision then put your trust in God..." (3:159).

In other words, the ideal imam must be gentle and forgiving, but firm in resolve when making decisions after consulting his community. These vital qualities complement the fundamentals of honesty, trust, and integrity in establishing the foundations of successful leadership.

Therefore, any prospective imam should have gone through a program of spiritual and character mentorship and training led by an experienced imam. Contacting previous mentors who can attest to his character development should be a basic first element in the interview process. Last but not least, the board must seek an ethics review from board members and/or co-workers from the applicant's previous posting.

\section{Broadening our Horizons}

Improving character is, in fact, the bedrock and goal of Islamic theology, as the Prophet said, "I was only sent to perfect a model of noble character" (Majma", vol. 8, hadith no. 191). At the same time, it must be based on and guided by sound knowledge. Obviously an imam also needs to be educated in the Islamic sciences, which were revealed and meticulously preserved to protect human welfare as a whole, to successfully fulfill his duty as a religious leader.

American Muslims are obliged to support our local seminaries so that they can become high-quality institutions in terms of staff and facilities, as well as to provide scholarships and stipends to low-income students who feel called to formally 
study Islam. Only a local seminary can establish a curriculum that properly addresses the mindset and needs of scholars and imams, who the community tasks with forming an ideal platform and priorities for its mosques. Each imam should go through a tailored "ordainment" process to learn the essential proper tools that he will need to lead his future congregation.

The notion of professional development was a hallmark of Islamic civilization's golden age, traditionally dated from the eighth to the fourteenth centuries. After all, Europe's modern idea of studying the seven liberal arts before specialization was taken from the Caliphate of Andalusia in the early tenth century (Lyons 2009). As a result of many Quranic passages coupled with the Prophet's emphasis on knowledge and intellectualism, early Muslims valued the systems of science and governance they learned from other civilizations (ibid). The Abbasid caliphate established the Bayt al-Hikma (House of Wisdom) to institutionalize the translation of other civilizations' scientific texts for the benefit of Muslims and to challenge them to transcend their predecessors' achievements (Morgan 2008). Muslims should invest in studying, re-creating, and improving upon successful church models across the US, for we can learn a great deal from their many struggles, trials, and errors.

Many of our fellow Christian and Jewish communities require their clergy to be trained in sciences outside of their respective religion's history and theology, having recognized that being a community leader requires more than "religious" knowledge. Before taking on a lead imam role, the applicant should go through complementary training in specific subjects within psychology, sociology, nonprofit management, and American history.

A trained imam should be viewed not as an employee of the board who must always follow their lead, but respected as a visionary leader attending to and consulting with the relevant boards and committees. After all, he spearheads all of the mosque's spiritually guided work in terms of strategy and initial development. Moreover, he is responsible for inspiring and encouraging others to step up and lead the work. The successful mosque model undoubtedly starts with a qualified, well-trained, and fully empowered imam. If a pious young man wants to dedicate himself to such a role while raising his family, then his salary must be equal to that of an average middle-class family living in the same area of the city.

In addition to an official imam, historically a male-only role, the mosque needs to encourage the development and establishment of official female scholarship and leadership positions, for their perspective adds a vital dimension to the Muslim community's growth, development, and representation. Islamic jurisprudence does not prohibit women from teaching mixed gatherings, and women teaching was a well-established quality, as the lives of our "mothers," among them Khadija, 'A'isha, Zainab, and Umm Salama, prove. In much of the premodern Muslim world, traditional female scholars were teaching the Islamic sci- 
ences to mixed gatherings in mosques as late as the thirteenth century (Nadwi 2013). We are seeing more female scholarship in mosques nowadays and, considering the American context, should promote this as standard mosque culture.

\section{The American Context and the Role of Custom in Islam}

As previously noted, Muhammad was an Arab as well as God's messenger. Studying his biography and Islamic jurisprudence reveals that some of what he taught and prioritized, such as laws related to marriage, war engagement, economic policies, and other fields were unquestionably influenced by his being a man of his time and environment (Sallabi 2005). This point cannot be overstated, for ignoring it has led to a host of problems in formulating a religious identity in America, such as an aversion to or fear of American culture, misogyny, a lack of critical thinking, not being politically or civically engaged, and so on. There is no question that culture and religion are interconnected realities. In order to thrive, native Muslim scholars should help them navigate a healthy balance and integration of culture, and religion and mosques should promote this balance.

Culture is the sum of a given society's collective beliefs, attitudes, and behaviors that may or may not be properly rooted in religion, whereas religion is the revealed teachings that underlay a life of faith. Ideally, religion both regulates and integrates with culture. In much of the world, culture controls a Muslim's religious identity to such an extent that many of them do not know why they believe or how to practice Islam. Much of an observant Muslim's religious life is regulated by a mainstream understanding; however, there are many instances of exaggerations, such as the heavy emphasis on black magic and the "evil eye" to explain problems of physical or mental health, cynophobia (the fear of dogs), or that women are a fitna (a spiritual trial) for men.

Other fabrications are believed to be rooted in religion, such as the idea that unmarried women and men must not intermingle with each other, that men are generally superior to women, or that one must make ablution after being touched by a dog. Without the concept of needing to review and authenticate our faith and practice through scripture, we perpetuate ignorance.

As Muslims migrate to the US, they often inadvertently create a multi-level identity crisis in their children. First, there is the natural inclination to teach their children their own culture and heritage, which is perfectly fine and healthy. However, many see their original homeland as a Muslim country, whereas their new homeland is a non-Muslim country. This can lead to varying degrees of ethnocentrism, in which Muslims attempt to raise their children as though they were from the "old country."

In many cases there is a direct or indirect negative attitude around being American or "like the Americans." This approach conflicts with the Prophet's approach in polytheistic Arabia, which was definitely the more immoral of the two. 
He simply communicated verses that rebuked his fellow Makkans' immoral elements rather than blaming them on Arabia or being Arab.

Actually, claiming to be Arab or even from Quraysh was common throughout his life. Some Makkan polytheists fought on the Muslims' side at the Battle of Hunayn. In the heat of that battle, he said, "I am the Prophet, no lie, and I am a child of Abdul-Muttalib" (Saḥịh al-Bukhārī, hadith no. 4315). In addition to emphasizing his prophethood, he was also stressing his cultural place within his society as well as his connection to the people, who regarded the polytheistic AbdulMuttalib as a cultural icon.

Moroccan, Brazilian, Nigerian, Egyptian, Indian, Russian, Turkish, and Indonesian Muslims are all equally Muslim with significantly different cultural traditions. Similarly, there should be a thriving American Muslim community that is seen as native to this land. Islam's success in any society is directly related to how well its scripture regulates and integrates with the local culture. Islam calls for a natural balance between culture and religion. Mosques should be nurturing a thriving American Muslim community dynamic. Forming mosques with another land's specific ethnic culture only reinforces the idea that Islam is both a foreign religion and related to a specific culture, when it is, in fact, a universal truth for everyone (34:28, 7:158). Mosque leadership should be instrumental in unifying Muslims, despite their rich diversity, and guiding them to best way of relating to American mainstream society.

All classical schools of Islamic jurisprudential thought recognize the fact that local culture and customs play an influential role in both deciding and prioritizing Islamic law. In general, the accepted explanation of this is "The general accepted attitudes, language, and practices of the majority of a society or a group among them which do not directly contradict clear authentic scripture are authoritative in Islamic law" (Khallaf 1942). The main evidence for this assertion is the oftmentioned scriptural word ma 'rüf, "something known to be good or acceptable." This is from both scripture as well as the local culture. I say "local" because while a minority immigrant group is free to follow its own culture, it should not be used as a standard for American Muslim legal realities, especially for those born and raised in the United States.

Each of the four Sunni schools of thought emphasize the need to both understand and treat the local culture as authoritative when interpreting and prioritizing religion, as long as it does not contradict its established teachings (Zuhaily 1986). The Hanafis say, "What is established by local custom is equal to what is established by scripture" (al-Sarkhasi, Kitāb al-Mabsūt). The Malikis say, "Acting upon local custom is a principle of juristic tradition of Imam Malik" (al-Qarafi, $A l$ Furūq). The Shafi' is say "The local custom is authoritative in Islamic law" (alGhazali, Al-Mustasf $\bar{a}$ ). The Hanbalis say, "What is not specifically outlined in the divine law is decided by the local custom" (al-Mardawi, Al-Tahrīr). 


\section{The Prophetic Attitude on Citizenship}

Messengers were sent from within communities because they must know the target audience's language and culture to relate to them, "It was a profound blessing that God sent to the believers a messenger from among themselves..." (3:164). Many exegetes refer to this ability as the "wisdom" mentioned in, "Call to the path of your Lord with wisdom..." (16:125).

These problems are further exacerbated and perpetuated by the commonly expressed concept that "American" is synonymous with "non-Muslim" or "immorality" in general, as in my "American friends" or, even worse, "Don't be like the Americans." A Muslim should not be a separatist or treat their non-Muslim neighbors and fellow citizens as "the other." Each prophet was sent to his own people, who, for the most part, rejected him. And yet God still describes their relationship as that of a collective "kinship or "family," if you will: "We sent to the people of "Ad their brother Hud saying to them, 'O My people, worship God alone as you have no deity beside Him..." (7:65). Even our beloved Prophet had the same idea, "The Messenger called out, 'O my Lord, truly my people have turned away from this Quran"” (25:30).

The Prophet and his earliest Companions were Arabs from Makka, mostly from the Quraysh. The town's polytheists both rejected and actively abused members of this small monotheistic minority. Considering our situation here, where we are generally welcomed and encouraged to follow and promote our religion, we should have no problem teaching our children that they are American Muslims.

However, there is a question over whether we should describe ourselves as "American Muslims" or "Muslim Americans." It could be just polemics, but I feel that as Muslims, we look at ourselves first as souls created by God in heaven and then as living in a body created from earth. Therefore I prefer "American Muslim," just as I prefer "Egyptian Muslim." So the proper noun, which mainly describes who and what we are, is "Muslim," and one way we are known by description (i.e., adjective) of worldly affiliation is "American" or any other nationality/culture.

It is natural for someone to love their homeland and feel connected to its people. That being said, a Muslim cannot be a nationalist or carry any sort of ethnocentric attitudes and behaviors. The Arabs used to say, "Support your fellow tribesman, whether the oppressor or the oppressed" (Fath al-Bāri). They meant it literally, and yet one day the Prophet said the exact same phrase to his Companions. This now seemed rather strange to them, and so they asked him about it in a different way, "We understand supporting the oppressed, but how could we support the oppressor? He replied, 'Stop them from oppressing people" (Sahịh alBukhārì, hadith no. 6952).

Notice how they naturally did not accept the oppression, even if it was the Prophet's literal suggestion or if their fellow Muslim or tribesman was the oppressor. As Muslims, we should be patriotic citizens of the country in which we hap- 
pen to live and strive to promote all that is good and beneficial while speaking out against and working to remove all forms of oppression and corruption.

American Muslims must not cut themselves off from the rest of society. In fact, Muslims should integrate into any society and learn from them, as this is the actual purpose of cultural diversity, "O humanity, We have created you all from male and female and made you into different tribes and nations so that you may get to know one another..." (49:13).

Every society, whether Muslim or non-Muslim, has its good and bad qualities and elements. Prophet Muhammad advised the believers on how they should deal with that, "The believer that intermingles with society and is patient with their harms is better than the one who does not intermingle with people and thus is not patient with them" (Adab al-Mufrad, hadith no. 300). This patience is manifested in knowing, following, and promoting your faith's values in order to alleviate the harms and corruption of your society. We are called to promote wholesomeness, justice, and benevolence while remaining true to our faith.

\section{The Language Barrier}

Language is the primary basis of any culture. Islam itself is not a culture, but rather a religion meant for all peoples. As mentioned above, Islam is meant to integrate with and regulate culture, not vice versa. Thus it should be presented and appreciated as something natural to anyone, regardless of what language they speak, "We only sent messengers to talk in the language of the people to whom they were sent so that they could properly communicate the message to them..." $(14: 4)$. Given that language is the most important tool in communication, God never sent any people a prophet from a foreign community. In other words, a native person speaking in the native tongue is the ideal way for the message to be properly communicated and received.

There is a widespread international culture among non-Arab Muslims, in which they use Arabic words while speaking their own languages. This idea has its roots in the growth of the early caliphate, which institutionalized Arabic as the government's official language. Conveniently, it is also the language of our sacred scriptures. With the influx of non-Arab converts, the caliphate prioritized the teaching of the scriptural and administrative governmental language. Many lands, such as present-day Palestine, Syria, Lebanon, Iraq, and North Africa, were inhabited by non-Arabs before the Prophet's teachings reached them. Their widespread adoption of Arabic was a significant achievement of Islamic civilization, as well as a great blessing to those land's Muslims.

On the other hand, close to $80 \%$ of Muslim lands, among them present-day mid/southwest Africa, Turkey, the Indian Subcontinent, Indonesia, and Malaysia, did not fully adopt Arabic. As a result, their Muslims naturally regret that. Combining the internal political dynamic among different faiths and doing what they 
could to adopt the scriptural language led to the Arabization of non-Arab languages. That made sense then and still does, for that is a culture that all Muslims know and are comfortable with. On the other hand, according to the previously quoted Quranic verses, it does not necessarily make sense to institute this same policy for American Muslims.

One of the main issues for many Muslims is the "name of God" debate, which also exists among Jews and Christians. I would like to highlight a couple of facts, since this issue can easily be an entire research field in itself. Many Muslims point out that Arabs from the Christian and Jewish communities refer to God as "Allah" as a reason to use it in English. The fact is that they do not do this because they believe that "Allah" is God's proper name, but rather because they realize that it represents similar words found in their Hebrew and Aramaic scriptures referring to God. Interestingly they still describe Allah in Arabic as the father, son and Holy Spirit (Rabb al-Majd 1923).

Others spread the mistaken claim that "Allah" shares the same etymology and phonetics in both Hebrew and Aramaic and was used by the Israelite prophets. My personal conviction is based on the intersection of Quranic teaching with anthropology, "Certainly, We have sent messengers to all nations saying worship God and avoid evil transgression..." (16:36). Thus I do not think God has a single phonetically singular "proper name." Rather, He revealed Himself to all peoples by the many descriptions - all of which are equally holy - He wanted us to know.

In fact, there is a word for the Creator/Supreme Being in every language spoken by the children of Adam [and Eve], and they are all quite different in their etymologies and phonetics. Therefore, Muslims are tasked with properly defining that word in their specific cultural context, for the Quran teaches us to tell the People of the Book, "... we believe in what was revealed to us and you, and our God and yours is one and the same..." (29:46).

Classical-era Arabic linguists and anthropologists debated the origin of the word "Allah." Many follow prominent scholars such as Sibawayh, as mentioned by Ibn Manthur in his great nine-volume encyclopedia Lisān al-'Arab (The Tongue of the Arabs). Their explanation is that the Arabs decided to combine the definitive article $a l$ (the) and the word iläh (something worshipped or deified) and dropped the hamza or the "i" at the beginning of the second word to make the pronunciation easier, thereby creating "Allah," meaning "the worshipped entity" or "the deity."

The Quran is replete with references to the Christians and Jews' special designation as "People of the Book." God even uses this title to call upon them, because they still possess and follow the revelations that God revealed to the Israelite prophets. Thus, we have a special relationship with them as fellow claimants to the Abrahamic covenant. Any Muslim who reads the Bible will find a huge overlap of similar to almost word-for-word passages. American Muslims live in a so- 
ciety whose general populace has names for our prophets and theological concepts. According to the verse "we only sent messengers speaking to their people in their native language" (14:4), our task is not to Arabize American culture, but rather to utilize English to familiarize our fellow citizens with God's final message to humanity, as revealed to Prophet Muhammad.

Some imams have followed this logic to an extent, often by speaking in Arabized English only when preaching to Muslims and then adjusting to an allEnglish vernacular when talking to non-Muslims about Islam. While it is important to reference scripture in its original language and to teach classical Arabic at the mosque, I suggest that mosque leadership should do its best to develop a general native-language discourse to engage in general communication and provide spiritual instruction. This is in keeping with the prophetic model. In addition to amplifying the reception and proper dissemination of Islam, it will also alleviate the confusion and unnecessary struggle that the current model creates for young people raised here, converts, and non-Muslims attending the mosque.

\section{Mission, Vision, and a Core Value-based Mosque}

The success of any institution is relative to the effectiveness of its governance and the quality of the work it produces. Both of these require three fundamental driving forces: clarity of mission/purpose, guiding inspiration, and mutual consultation. In its capacity as a book of guidance for a strong faith community, the Quran stresses these underlying themes repeatedly.

A lack of clear, specific inspirational direction opens the door for a host of potential problems such an as ethnicity-focused community, personal power plays, a lack of direction or accountability, and similar issues. At the Muslim Community Center of Charlotte (MCC), we researched and consulted with scholars, community leaders, and social scientists to form a mission, vision, and core value-based system to inspire and guide our work. These concepts, which are standard in strategic management, represent the fundamental points for any institution trying to achieve its goals. As such, it can be used to hold people accountable and thereby avert the problems associated with a personal-based dominance of an institution. These concepts are that the institution's authority is superior to that of any individual, board, employee, and committee.

Our mission statement is a four-step gradual relational process: Devotion to God, Striving for Excellence, Nurturing American Muslims, and Engaging in the Service of Society.

Our fundamental and primary purpose, establishing and promoting sincere pious worship of God, leads us on a path that always sees room for improving our knowledge, faith, and character. God is calling us toward a work ethic and functional presentation of Islam that represents the highest standards of excellence. As we all work individually on the first two elements, we are all invested in Islam 
becoming a vibrant, thriving faith community, one well integrated into mainstream American society. All three of these elements lead to and help us fulfill our ultimate callings of altruism and benevolence.

Our vision is a standard designed to enable us to materialize our values through our mission: A Charlotte Community Built on Virtue and Cooperation.

The Muslim community should be a beacon for morality in any society. People will naturally realize Islam's beauty and value if we internally work to understand and practice it correctly. Our goal is for our city to appreciate us as an integral morally uplifting element so that we can find ways to work together in supporting, improving, and reforming it.

A mission statement, which is often broad and far-reaching, requires a specific value system to guide it. MCC's five-point value system is outlined below.

Welcoming. For us to succeed, we must cultivate a comfortable environment for all attendees. Everyone is at a unique place on the spiritual path, and folks need room to digest faith and grow at their own pace. Their mosque must be a caring warm-spirited space, for providing encouragement and an easy-going attitude are hallmarks of the prophetic model.

Scriptural. Guided by the Quran and the Prophet's authenticated teachings, we must intellectualize our faith through a direct understanding of scripture and scholarly interpretation.

Relevant. We respect the rich, vast legacy of Islamic scholarship. After all, our Prophet referred to scholars as "the inheritors of the prophets." (Sunan $A b \overline{1}$ $D \bar{a} w \bar{u} d$, hadith no. 3641). As has always been the norm in the Muslim world, we take from and present the interpretations and priorities of local scholars raised in the United States to guide our understanding and practice of Islam.

Benevolent. Our attitude and programming should be centered on spending our time, skills, and wealth on caring for each other, as well as for our neighbors, the poor, the weak, the oppressed, and the environment. Our interpersonal relationships should be rooted in and expressed with compassion, gentleness, and love.

Diverse. The mosque should emphasize building genuine relationships across our differences. We are a spiritual family with a lot to learn from each other. In order for generations to grow and thrive in this country, mosques must uplift and empower the participation and leadership of the entire community, especially that of women and youth.

All programs in our mosque are governed by and emphasize the mission statement of working toward the vision statement. The core value system guides the organization's system of work. This mission, vision, and core value-based system is a patented method of protecting the reason for which the organization was established, according to the agreed-upon philosophy from which it arose. This removes most conflicts and structural problems. 
The two most harmful inhibiting factors to mosque growth and stability are leaders who crave power and the congregants' free-for-all ideological and cultural battles. These problems are either prevented or mitigated in an institution governed and guided by this very system.

\section{Conclusion}

The American Muslim community is at a crossroads, especially when it comes to faith and community. As many of the first generation's children are now adults, there has been a visible decline in mosque attendance, especially among the two foundational elements of future generations: women and youth. Ideology and identity can either be a one-two punch or a double whammy for any society. Unfortunately, most mosques do not have fully trained imams. But even if they do, they are missing the other staff needed to establish a successful, dynamic, and thriving community.

The imam is the leader of the greater mosque community. His job is to actively inspire, motivate, and mobilize his congregation to implement their faith. In order to achieve this goal, he must go through a holistic educational training regimen and be able to relate to the diversity found within his congregation and within the surrounding non-Muslim community. To ensure long-term success, the mosque and its leadership must integrate with the surrounding society so that it can be appreciated and revered as an indigenous faith community. Many Muslims confuse integration with assimilation. If one assimilates into a different group, then s/he becomes just like them, whereas integration means to live among people while maintaining one's unique identity.

In order to avoid ethnic or religious group politics as well as the domination of powerful personalities, an American mosque should set a mission, vision, and core value-based system to permanently govern the entire institution. Such a system must incorporate the realities of scriptural priority as they relate to individual and collective spirituality, empower women and youth, accept the agreed-upon role of local custom, successfully manage an integrated congregation, and work toward the universal betterment of society at-large. Recent data regarding mosque attendance and activity demonstrate that these specific avenues, represented within their respective religious models, are necessary for a religious institution or congregation to succeed and thrive. Moreover, these values illustrate an original prophetic guide to what a cohesive and resilient Muslim community should look like, regardless of the reality of Western standards and society.

\section{Bibliography}

Al-Bukhari. Șaḥịh al-Bukhārī.

Bennet, William J. 1993. The Book of Virtues: A Treasury of Great Moral Stories.

New York: Simon \& Schuster. 
Bhabha, Homi K. 2004. The Location of Culture. 2nd ed. Routledge Classics: London and New York.

Hart, Michael H. 2000. The 100: A Ranking of the Most Influential Persons in History. New York: Citadel.

Institute for Social Policy and Understanding. 2016. "Reimagining Muslim Spaces." https://www.ispu.org/social-policy/reimagining-muslim-spaces/.

Khallaf, Abdul-Wahhab. 1942. The Science of Usool al-Fiqh. Egypt: Library of Islamic Da'wah Shabab al-Azhar.

Lyons, Jonathan. 2010. The House of Wisdom: How the Arabs Transformed Western Civilization. New York: Bloomsbury Press.

Morgan, Michael H. 2008. Lost History: The Enduring Legacy of Muslim Scientists, Thinkers, and Artists. Washington, DC: National Geographic.

Muslim. Șạị Muslim.

Nadwi, Muhammad A. 2013. Al-Muhaddithāt: The Women Scholars in Islam. Interface Publications.

Sallabi, Ali. 2005. The Noble Life of the Prophet. Saudi Arabia: Dar-us-Salam Publications.

Schaller, Lyle E. 1980. The Multiple Staff and the Larger Church. Abingdon Press, Nashville, TN.

Zuhaily, Wahbah. 1986. Usool al-Fiqh in Islam. Damascus: Dar al-Fikr.

Rabb al-Majd. 1923. Al-Nīl al-Masīḥiyah bi al-Manākh. Egypt. 